\title{
Peran Persepsi Dalam Memediasi Pengaruh Marketing Mix pada Niat Beli Wisatawan di Bali Zoo
}

\author{
Ni Nyoman Rsi Respati ${ }^{1}$ \\ Fakultas Ekonomi dan Bisnis \\ Universitas Udayana, Indonesia. \\ Email: rsi_respati@unud.ac.id
}

\author{
Ni Made Asti Aksari2 \\ Fakultas Ekonomi dan Bisnis \\ Universitas Udayana, Indonesia
}

\begin{abstract}
ABSTRAK
Penelitian bertujuan mengetahui peran persepsi dalam memediasi pengaruh marketing mix terhadap niat beli. Penting bagi para pelaku bisnis yang bergerak dalam industri pariwisata untuk mempelajari kebutuhan wisatawan sehingga tepat dalam menawarkan produknya. Penelitian ini dilakukan di Kebun Binatang yang berlokasi di Kabupaten Gianyar,Bali. Populasi dalam penelitian ini adalah wisatawan asing dan domestik yang berkunjung ke Bali Zoo. Dari proses sampling diperoleh 200 responden yang mengisi kuesioner dengan lengkap. Teknik pengambilan sampel yang digunakan adalah metode random sampling. Penelitian ini menggunakan teknik analisis jalur (path analysis) untuk mencari pengaruh langsung dan tidak langsung variabel independent pada variabel dependen. Untuk memperoleh data dan mengukur indikator penelitian menggunakan instrumen kuesioner dan diukur dengan skala Likert. Hasil penelitian ini menunjukkan bahwa persepsi memainkan peran penting dalam mempengaruhi niat beli. Demikian pula marketing mix dan persepsi memiliki pengaruh yang positif terhadap niat beli. Hal ini perlu diperhatikan oleh manajemen Bali Zoo.
\end{abstract}

Kata Kunci : $\quad$ Marketing Mix; Persepsi; Niat Beli.

\section{The Role of Perceptions in Mediating the Effect of Marketing Mix on Intention to Buy Of Tourist at Bali Zoo}

\section{ABSTRACT}

This study aims to determine the role of perception in mediating the effect of marketing mix on purchase intention. It is important for business people whom engaged in the tourism industry to offering the right product. This research is located at Bali Zoo Gianyar,Bali. The population were foreign and domestic tourists who visited Bali Zoo. From the sampling process, 200 respondents completed the questionnaire completely. The sampling technique used was random sampling method. This study uses path analysis techniques to find the direct and indirect effects of independent variables on the dependent variable. To obtain data and measure research indicators using a questionnaire instrument and measured by a Likert scale. The result of this study shows that perception plays an important role in influencing purchase intention. Marketing mix and perception become factors influences purchase intention. This needs to be taken into account by the management of Bali Zoo.

Keywords: $\quad$ Marketing Mix; Perception; Purchase Intention.

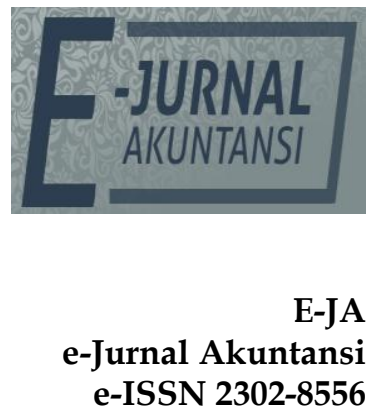

Vol. 29 No. 2

Denpasar, November 2019

Hal. 698-715

Artikel masuk:

29 Oktober 2019

Tanggal diterima: 18 November 2019 


\section{PENDAHULUAN}

Perkembangan teknologi beberapa dasawarsa ini memicu kemajuan segala bidang industri primer, sekunder, manufaktur, ekstraktif, konstruksi hingga industri jasa kian pesat. Hal ini menyebabkan persaingan disegala bidang semakin ketat sehingga menimbulkan kepenatan dalam menjalankan keseharian. Fenomena ini membangkitkan penawaran berbagai macam produk dari industri jasa khususnya pariwisata. Kemajuan teknologi juga memudahkan para calon wisatawan memperoleh informasi atau gambaran mengenai tempat wisata yang kelak ingin dikunjungi. Indonesia yang dijuluki negara seribu pulau sangat berpotensi dalam menawarkan destinasi wisata yang unik dan menarik. Mulai dari Sabang sampai Merauke, Negara ini kaya akan adat istiadat, suku, bahasa, budaya, cerita rakyat, dan berbagai jenis ragam masakan yang dapat dinikmati wisatawan. Wisatawan dibedakan menjadi dua yaitu wisatawan asing dan domestik (Pendit, 1999). Wisatawan asing (internasional) adalah orang yang melakukan perjalanan wisata ke luar negeranya dan Wisatawan domestik (nasional) adalah penduduk Indonesia yang melakukan perjalanan di wilayah Indonesia diluar tempatnya berdomisili, dalam jangka waktu sekurangkurangnya 24 Jam atau menginap kecuali kegiatan yang mendatangkan nafkah ditempat yang dikunjungi. Wisatawan yang berkunjung ke suatu daerah biasanya benar-benar ingin menghabiskan waktunya untuk bersantai, menyegarkan pikiran dan benar-benar ingin melepaskan diri dari rutinitas kehidupan sehari-hari (Kusumaningrum, 2009).

Bali sebagai salah satu pulau unggulan Indonesia dengan keunikan adat istiadat dan keindahan alam perekonomiannya masih sangat bergantung dengan industri pariwisata, Oleh sebab itu sangat penting bagi pelaku bisnis pariwisata untuk memberikan penawaran produk yang tepat bagi wisatawan agar tertarik untuk datang ke Bali. Berbagai penawaran pun diciptakan, mulai dari produk berupa barang hingga penawaran sebuah pengalaman atau experience. Tidak sedikit wisatawan ingin mencoba pengalaman menarik yang tak terlupakan di daerah wisata yang akan dikunjungi sebagai momen berharga yang bisa dikenang. Penelitian ini dilakukan di Bali Zoo, Kebun binatang yang berlokasi di Singapadu, Gianyar, Bali. Kabupaten Gianyar yang merupakan pusat seni dan adat istiadat budaya Bali dinilai mengangkat pariwisata Bali. (Tempo.co: 2019). Penelitian ini menganalisis peran persepsi dalam memediasi marketing mix terhadap niat beli.

Persepsi didefinisikan oleh (Kotler \& Keller, 2008) sebagai proses seorang individu dalam memilih, mengorganisasikan dan menafsirkan masukan dan informasi untuk menciptakan sebuah gambar yang bermakna tentang dunia. Persepsi merupakan aktivitas penting yang menghubungkan konsumen individual dengan kelompok, situasi dan pengaruh pemasar (Hawkins DI, Motherbaugh, David, 2013). Menurut (Suprapti, 2010), persepsi didefinisikan sebagai proses yang dilalui seseorang untuk memilih, mengorganisasi, dan menginterpretasi stimuli ke dalam sebuah gambaran tentang dunia, yang memiliki arti atau makna dan bersifat koheren. Persepsi meliputi semua proses yang dilakukan seseorang dalam memahami informasi mengenai lingkungannya, sehingga proses pemahaman ini akan mempengaruhi cara seseorang mempengaruhi persepsinya (Wardhani, Sumarwan, \& Yuliati, 2016). 
Penelitian Sukawati dan (Wiryantari, I,C., 2016) menunjukkan bahwa persepsi berpengaruh positif dan signifikan terhadap niat beli.

Marketing mix terdiri atas produk, harga, promosi dan lokasi merupakan faktor yang mempengaruhi perilaku konsumen (Kotler, P. \& Armstrong, 2008). Penelitian yang dilakukan oleh (Wardhani, Sumarwan, \& Yuliati, 2016) menunjukkan bahwa produk dan lokasi dalam marketing mix berpengaruh positif dan signifikan terhadap persepsi. Demikian juga dalam penelitian yang dilakukan oleh (Sutopo, I., 2016) menyebutkan bahwa produk berpengaruh positif dan signifikan terhadap persepsi. Terdapat research Gap pada variabel harga dan promosi (marketing mix) dalam penelitian (Wardhani, Sumarwan, \& Yuliati, 2016) yang menyebutkan harga dan promosi tidak signifikan terhadap persepsi. Sedangkan penelitian yang dilakukan oleh (Arokiosamy. A.Raj, 2012) menunjukkan bahwa harga berpengaruh positif dan signifikan terhadap persepsi, didukung oleh penelitian yang dilakukan oleh (Han \& Ryu, 2009) menunjukkan promosi berpengaruh positif dan signifikan terhadap persepsi dan penelitian (Stamboulis \& Skayannis, 2003) menunjukkan bahwa lokasi berpengaruh positif dan signifikan terhadap persepsi.

Niat beli adalah perilaku konsumen yang muncul sebagai respon terhadap objek yang menunjukkan keinginan pelanggan untuk melakukan pembelian (Kotler \& Keller, 2008). Niat beli juga dapat diartikan sebagai keinginan untuk membeli yang merupakan bagian dari proses menuju kearah tindakan pembelian yang dilakukan oleh seorang konsumen, (Hansudoh, 2012). Niat beli ini menciptakan suatu motivasi yang terus terekam dalam benaknya dan menjadi suatu keinginan yang sangat kuat yang pada akhirnya ketika seorang konsumen harus memenuhi kebutuhannya akan mengaktualisasikan apa yang ada dalam benaknya itu (Murti, 2014). Dalam penelitian sebelumnya persepsi berpengaruh secara positif dan signifikan terhadap niat beli (Suarjana, K,. Suprapti, 2018). Niat beli sebuah produk dapat dipengaruhi oleh persepsi (Wardhani, Sumarwan, \& Yuliati, 2016). Menciptakan persepsi kualitas atau nilai wisatawan bukanlah tugas yang mudah, Karena pengalaman (experience) ini cenderung kompleks dan tidak berwujud (Zeithaml VA, 2000).

Bali Zoo merupakan sebuah kebun binatang yang berlokasi di Gianyar, Bali. Kebun binatang ini memiliki luas 12 hektare. Terdapat 75 jenis spesies dengan total keseluruhan sebanyak 500 satwa. Satwa yang ada di Bali Zoo berasal dari Indonesia, Afrika, India dan Eropa. Selain sebagai kebun binatang, Bali Zoo merupakan sebuah lembaga konservasi dan tempat pendidikan, pelatihan dan tempat kegiatan penelitian bagi pelajar. Keberadaannya sebagai lembaga konservasi terdaftar di Kementerian Kehutanan Republik Indonesia melalui SK Menteri RI No. 68/KPTS-11/2001 tertanggal 15 Maret 2001. Sebagai salah satu pelaku bisnis pariwisata di Bali, Bali Zoo tidak hanya menawarkan pengalaman melihat satwa di siang hari namun juga pengalaman atau experience dinner sambil melihat dan menyentuh beberapa binatang nokturnal atau binatang yang aktif pada malam hari. Program ini diberi nama Dinner with the Great Elephant. Program ini dibuat untuk menarik perhatian wisatawan asing maupun domestik untuk meningkatkan kunjungan ke Bali Zoo. Menurut wawancara dengan manajer pemasaran Bali Zoo, Putu Setiawan, pada bulan Januari 2019, Total kunjungan wisatawan yang datang ke Bali Zoo meningkat $14,06 \%$ namun jumlah 
kunjungan ke Dinner with The Great Elephant turun sebanyak 36\% dibandingkan dengan tahun sebelumnya.

Penelitian ini menganalisis peran persepsi wisatawan dalam memediasi marketing mix yang terdiri atas produk, harga, promosi dan lokasi terhadap niat beli experience Dinner with The Great Elephant yang ditawarkan oleh Bali Zoo. Penelitian yang dilakukan (Wardhani, Sumarwan, \& Yuliati, 2016) merupakan model acuan yang digunakan dalam penelitian ini. Untuk menyesuaikan keadaan dengan obyek penelitian ada beberapa indikator dari penelitian (Wardhani, Sumarwan, \& Yuliati, 2016) yang dikurangi dan ditambahkan. Penelitian ini penting dilakukan agar pelaku bisnis pariwisata dan mahasiswa dapat menggunakan alat yang tepat untuk membentuk persepsi wisatawan dimana tujuannya adalah terciptanya niat beli terhadap produk yang ditawarkan.

Hasil penelitian ini diharapkan dapat memberikan tambahan referensi dan bahan acuan dalam perbaikan pola pembelajaran mahasiswa manajemen terkait dengan niat beli, produksi, harga, promosi dan lokasi dimediasi oleh persepsi wisatawan sebagai konsumen. Kerangka konseptual adalah sintesa tentang hubungan antar variabel yang disusun dari berbagai teori yang telah dideskripsikan, selanjutnya dianalisis secara kritis dan sistematis, sehingga menghasilkan sintesa tentang hubungan antar variabel yang diteliti (Sugiyono, 2010). Kerangka konseptual penelitian ini dapat disajikan dalam Gambar 1.

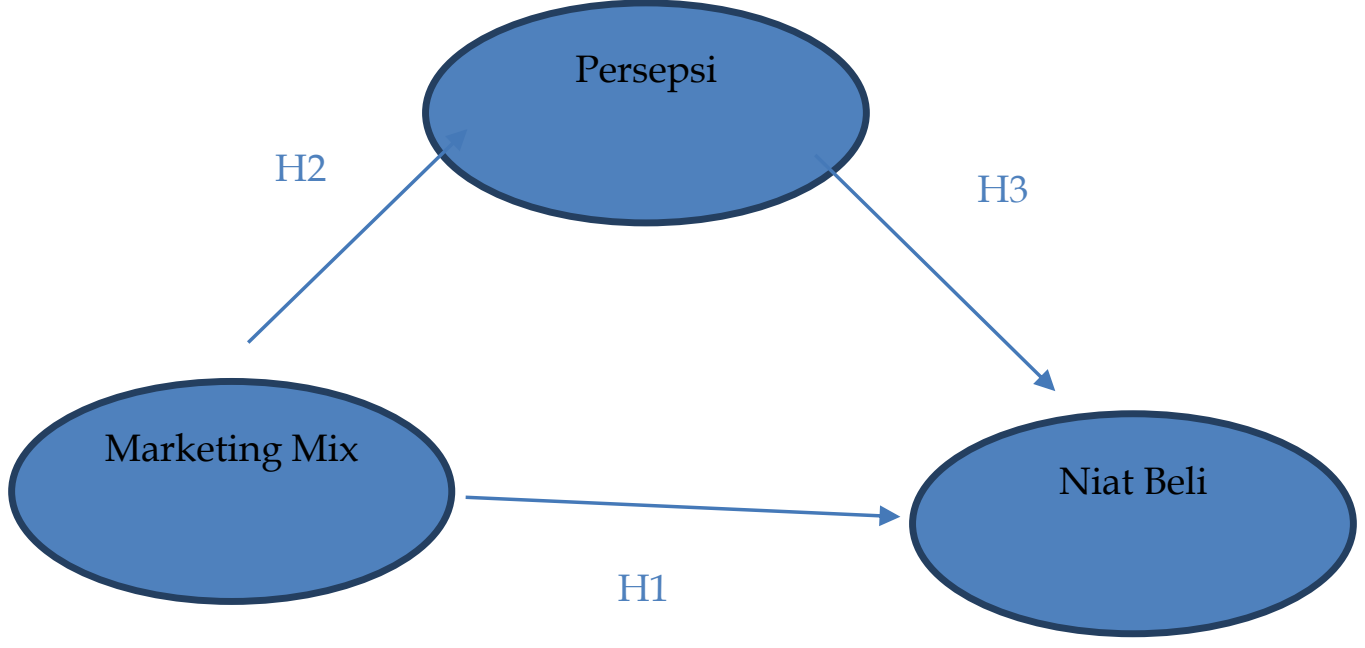

Gambar 1. Kerangka Konseptual Penelitian

Sumber: Data Penelitian,2019

Produk dibeli oleh konsumen karena dapat memenuhi kebutuhan dan memberi manfaat tertentu. Produk (Kotler \& Keller, 2008) adalah segala sesuatu yang dapat ditawarkan ke pasar untuk mendapat perhatian, dibeli, digunakan atau dikonsumsi yang dapat memuaskan keinginan atau kebutuhan. Menurut (Kotler \& Keller, 2008) perusahaan sebaiknya perlu secara matang mempertimbangkan pemilihan lokasi usaha untuk pengembangan masa depan. Dapat dipertimbangkan bahwa variabel lokasi adalah hal yang dipertimbangkan oleh konsumen. Hasil penelitian (Fure, 2013) menyatakan bahwa produk dan lokasi berpengaruh signifikan terhadap niat beli. Peranan penetapan harga akan menjadi sangat penting terutama dalam keadaan persaingan yang semakin 
tajam dan perkembangan permintaan yang terbatas. (Gitosudarmo, 2008) mengemukakan bahwa harga adalah sejumlah uang yang dibutuhkan untuk mendapatkan sejumlah barang beserta jasa-jasa tertentu atau kombinasi keduanya. (Swastha, 2014) menyatakan bahwa promosi dipandang sebagai kegiatan komunikasi pembeli dan penjual dan merupakan kegiatan yang membantu dalam pengambilan keputusan di bidang pemasaran serta mengarahkan dan menyadarkan semua pihak untuk berbuat lebih baik. Dalam penelitian Rizky dan Yasin (2014) mengatakan bahwa harga dan promosi berpengaruh positif terhadap niat beli. Dalam penelitian marketing mix wandy dan Dharmayanti (2014) memiliki pengaruh signifikan terhadap niat beli

$\mathrm{H}_{1}$ : Marketing mix memiliki efek yang positif terhadap niat beli.

Rustandi (2012) menyatakan bahwa produk mempengaruhi persepsi, selain itu (Tjiptono, 2008) menyatakan bahwa dasar pengambilan keputusan pembelian dapat dilihat melalui atribut produk. Penelitian yang dilakukan oleh (Wardhani, Sumarwan, \& Yuliati, 2016) faktor produk berpengaruh secara signifikan terhadap persepsi konsumen. Faktor terpenting dari harga sebenarnya bukan harga itu sendiri (objective price) akan tetapi harga subyektif, yaitu harga uang yang dipersepsikan oleh konsumen. Apabila konsumen mempresentasikan produk A harganya tinggi/mahal, maka hal ini akan berpengaruh positif terhadap "perceived quality dan perceived sacfrifice", artinya konsumen mungkin memandang produk A adalah produk berkualitas, oleh karena itu wajar apabila memerlukan pengorbanan uang yang lebih mahal (Bachriansyah, 2011). Semakin tinggi harga maka semakin tinggi nilai persepsi seseorang akan produk/jasa yang ditawarkan (Fure, 2013). Dalam melakukan promosi, pemasar harus berani menawarkan suatu kreativitas sehingga produk yang ditawarkan terlihat unik dimata konsumen. Menurut Wells, Burnett dan Moriarty (1995) dalam Dwiyanti (2008), melalui iklan, orang dapat mempunyai opini yang menyenangkan atau tidak menyenangkan terhadap produk yang diiklankan. Hasil penelitian tersebut menyatakan bahwa iklan mampu menciptakan daya tarik yang dapat membuat produk yang diiklankan menjadi menarik bagi konsumen. Tempat atau lokasi adalah sebuah titik tertentu yang dipilih oleh perusahaan untuk melaksanakan segala aktivitas usahanya, dimana titik tersebut mempunyai pengaruh terhadap strategi-strategi usaha dari perusahaan yang bersangkutan (Tjiptono, 2008). Menurut (Listyorini, Analisis Faktor-Faktor Gaya Hidup dan Pengaruhnya Terhadap Pembelian Rumah Sehat Sederhana Studi Pelanggan Rumah Dinar Mas PT Ajisaka Semarang, 2012) perubahan lingkungan yang dinamis menyebabkan studi gaya hidup konsumen dapat membantu pemasar memahami bagaimana konsumen berpikir dan memilih berbagai alternative. Menurut (Fure, 2013) Lokasi berpengaruh signifikan terhadap minat beli konsumen.

$\mathrm{H}_{2}$ : Marketing mix memiliki efek yang positif terhadap persepsi.

Konsumen akan menampakan perilaku setelah melakukan persepsi terhadap keputusan apa yang diambil dalam membeli suatu produk (Wahyuni,2008). Value juga merupakan kualitas yang diterima konsumen sesuai dengan harga yang dibayarkan (Zeithaml VA, 2000) Hasil penelitian (Wiryantari, I,C., 2016) menyebutkan bahwa persepsi nilai berpengaruh terhadap niat beli. Merk bukan hanya symbol, namun merek juga memberikan arti bahwa suatu produk mempunyai nilai tertentu (Pepadri, 2002). Hasil penelitian (Novansyah, 
2016) juga menyebutkan persepsi merek mewah berpengaruh positif dan signifikan terhadap niat beli. Konsumen menekankan bahwa keuntungan yang diterima dari suatu produk atau jasa merupakan suatu komponen yang penting dalam value. Penelitian yang dilakukan oleh (Suarjana, K,. Suprapti, 2018) menyatakan bahwa persepsi harga berpengaruh positif dan signifikan terhadap niat beli.

$\mathrm{H}_{3}$ : Persepsi memiliki pengaruh yang positif terhadap niat beli.

Persepsi didefinisikan oleh (Kotler \& Keller, 2008) sebagai proses seorang individu dalam memilih, mengorganisasikan dan menafsirkan masukan dan informasi untuk menciptakan sebuah gambar yang bermakna tentang dunia. Persepsi merupakan aktivitas penting yang menghubungkan konsumen individual dengan kelompok, situasi dan pengaruh pemasaran (Hawkins DI, Motherbaugh, David, 2013). Hasil penelitian Arsinta dan Purnami (2015) menyatakan bahwa persepsi nilai berpengaruh positif terhadap niat beli. Penelitian yang dilakukan oleh Rizka (2016) menyatakan persepsi nilai, persepsi merek dan persepsi harga secara simultan berpengaruh signifikan terhadap minat berkunjung wisatawan. Hasil penelitian Poernomo (2009) menunjukkan adanya hubungan yang positif antara persepsi dengan marketing mix.

$\mathrm{H}_{4}$ : Marketing mix memiliki efek positif terhadap niat beli melalui persepsi.

\section{METODE PENELITIAN}

Penelitian ini dilakukan untuk menjelaskan hubungan pengaruh variabel Marketing mix terhadap niat beli, pengaruh marketing mix terhadap persepsi, dan pengaruh persepsi terhadap niat beli, serta peran persepsi dalam memediasi pengaruh marketing mix terhadap niat beli. Metode yang digunakan adalah metode asosiatif untuk mengetahui sebab akibat dari variabel yang mempengaruhi terhadap variabel yang dipengaruhi. Populasi dalam penelitian ini adalah wisatawan asing maupun wisatawan domestik yang berkunjung ke Bali Zoo Jl Raya Singapadu Sukawati Gianyar pada bulan Mei dan Juni 2019. Sampel yang digunakan dalam penelitian ini adalah wisatawan asing dan domestik, Pengambilan sampel dari populasi yang ada dilakukan secara random sampling yaitu setiap wisatawan memiliki kesempatan yang sama dalam mengisi kuesioner. Untuk memperoleh data dan mengukur indikator penelitian menggunakan instrumen kuesioner dan diukur dengan skala likert. Total jumlah sampel adalah sebanyak 200 orang responden yang telah mengisi kuesioner dengan lengkap. Penelitian ini menggunakan teknik analisis jalur (path analysis) untuk mencari pengaruh langsung dan tidak langsung variabel independen pada variabel dependen.

Objek dari penelitian ini adalah pengaruh Marketing mix terhadap niat beli, pengaruh marketing mix terhadap persepsi, pengaruh persepsi terhadap niat beli dan peran persepsi memediasi pengaruh marketing mix terhadap niat beli. Variabel-variabel yang dianalisis dalam penelitian ini adalah: variabel eksogen (X) yaitu marketing mix, variabel mediasi (M) yaitu persepsi dan variabel endogen $(Y)$ yaitu niat beli.

Empat komponen yang tercakup dalam kegiatan marketing mix 4P yaitu; Produk (Product), Harga (Price), Promosi (Promotion) dan Lokasi (Place). Indikator tersebut selanjutnya diukur dengan kuesioner yang diaptasi dari penelitian 
Wardana, Sumarwan dan Yuliati (2015) serta indikator-indikator yang diaptasi dari penelitian Wandy dan Dharmayanti (2014). Sehingga diperoleh item 11 pertanyaan untuk mengukur variabel ini, yaitu diantaranya; 1) Penasaran akan produk adalah rasa ingin tahu mengenai produk yang ditawarkan oleh Bali Zoo dalam hal ini pengalaman 'Dinner with the Great Elephant' 2) Produk yang menarik dalam hal ini yaitu merangsang rasa ingin tahu mengenai pengalaman 'Diner with The Great Elephant' 3) Pengalaman yang bernilai adalah pengalaman berharga sebagai kenangan pada saat berwisata, 4) Produk yang unik yaitu pengalaman 'Dinner with The Great Elephant' beda dari penawaran pengalaman biasa.5) Harga terjangkau adalah harga yang masih masuk akal bagi wisatawan, 6) Bersedia membayar harga yang ditawarkan yaitu penawaran ini lebih condong dilihat dari pengalaman yang ditawarkan atau produknya dibandingkan dilihat dari harga yang ditawarkan. 7) Tampilan promosi menarik yaitu dalam salah satu media promosi gambar 'Dinner with The Great Elephant' merangsangrasa ingin tahu. 8) Membuat ingin mencoba yaitu tampilan gambar pada media promosi menimbulkan keinginan mencoba pengalaman 'Dinner with the Great Elephant'. 9) Pernah melihat iklan dalam hal ini yaitu wisatawan pernah melihat penawaran pengalaman 'Dinner with The Great Elephant' di Internet. 10) Lokasi mudah diakses adalah lokasi 'Dinner with The Great Elephant' yang berlokasi di Bali Zoo Sukawati Gianyar mudah dicari, 11) Lokasi dekat dengan tempat wisata yaitu lokasi 'Dinner with the Great Elephant' di Bali Zoo letaknya strategis karena dekat dengan tempat wisata lain yang ingin dikunjungi juga oleh wisatawan.

Niat beli dapat diklasifikasikan sebagai salah satu komponen dari perilaku kognitif konsumen tentang bagaimana sebuah individu bermaksud untuk membeli merek tertentu (Ling et al, 2010). Niat beli dibagi menjadi 4 indikator yaitu sebagai berikut; 1) Ingin mengetahui lebih dalam yaitu wisatawan berniat untuk mecari informasi lebih dari yang diketahuinya melalui media promosi. 2)Mempertimbangkan untuk membeli yaitu pikiran dalam menentukan pembelian pengalaman 'Dinner with the Great Elephant' 3)Tertarik untuk mencoba yaitu rasa ingin atau niat membeli pengalaman 'Dinner with the Great Elephant'

Persepsi dalam penelitian ini merupakan proses yang dilalui wisatawan menginterpretasi stimuli kedalam sebuah gambaran tentang pengalaman 'dinner with the great elephant'. Persepsi diukur dengan menggunakan empat indikator yaitu 1) Pengalaman yang menyenangkan adalah rasa gembira yang timbul bila mencoba pengalaman 'Dinner with the Great Elephant' 2) Menambah pengetahuan mengenai binatang nokturnal yaitu masuk kedalam persepsi nilai dimana pengalaman ini dapat memberikan nilai tambah bagi wisatawan. 3) Harga tiket sesuai yaitu masuk kedalam persepsi harga dimana harga tiket pegalaman 'Dinner with The Great Elephant' sesuai dengan pengalaman yang ditawarkan. 4) Rasa bangga dalam hal ini masuk dalam persepsi merk yaitu adanya rasa bangga bila pernah mencoba pengalaman ini di Bali Zoo.

Data kualitatif dalam penelitian ini berupa pendapat responden yang diuraikan dalam kuesioner. Data kuantitatif dari penelitian ini adalah hasil dari pengolahan kuesioner. Data primer yang digunakan dalam penelitian ini adalah data yang diperoleh langsung dari responden seputar variabel 
yang dimaksud yaitu marketing mix, persepsi dan niat beli. Data sekunder dalam penelitian ini adalah data yang diperoleh dari Bali Zoo, yaitu profil Bali Zoo. Populasi dalam penelitian ini adalah wisatawan asing dan domestik yang berkunjung ke Bali Zoo. Penelitian ini menggunakan sebanyak 18 indikator, sehingga banyaknya responden yang digunakan untuk sampel ditetapkan 200 orang responden. Metode pengumpulan data yang digunakan berupa kuesioner yang disebar langsung di Bali Zoo.

Pemilihan sampel menggunakan teknik purposive sampling. Sampel dalam penelitian ini memiliki karakteristik sebagai berikut: 1) Responden merupakan wisatawan asing dan domestik yang sedang berkunjung ke Bali Zoo dengan alasan responden mengetahui lokasi Bali Zoo dan penawaran 'dinner with the great elephant', 2) Responden dengan pendidikan minimal SMA/sederajat. Pertimbangan ini digunakan dengan alasan seseorang dengan pendidikan minimal SMA/sederajat dianggap telah mampu memahami dan mengerti mengenai pertanyaan yang terdapat dalam kuesioner dan dapat memberikan jawaban yang obyektif.

\section{HASIL DAN PEMBAHASAN}

Pengambilan sampel (sampling) dari populasi yang ada dilakukan secara random sampling dengan tujuan memberikan kesempatan yang sama bagi wisatawan. Jumlah responden yang memenuhi kriteria dan lengkap mengisi kuesioner berjumlah 200 orang. Dari hasil penyebaran kuesioner didapatkan data mengenai karakteristik demografi responden seperti nama, jenis usia responden, pekerjaan, jenis kelamin dan negara asal.

Tabel 1. Karakteristik Responden Menurut Usia

\begin{tabular}{ccc}
\hline Usia & Jumlah Responden & Persentase \\
\cline { 2 - 3 } & (Orang) & $(\%)$ \\
\hline 15 - 24 Tahun & 38 & $19 \%$ \\
25 - 34 Tahun & 88 & $44 \%$ \\
$35-44$ Tahun & 41 & $20.50 \%$ \\
45 - 54 Tahun & 23 & $11.50 \%$ \\
$>55$ Tahun & 10 & $5 \%$ \\
Total & 200 & $100 \%$ \\
\hline
\end{tabular}

Sumber: Data Penelitian, 2019

Dari Tabel 1. menunjukkan bahwa responden yang terbanyak berusia 25 tahun sampai dengan 34 tahun sebanyak 88 orang $(44 \%)$ dan jumlah yang terkecil yaitu berusia di diatas 55 tahun sebanyak 10 orang (5\%). Berdasarkan pekerjaan, distribusi frekuensi responden dapat ditunjukkan dalam Tabel 2 . Dimana responden terbanyak yaitu karyawan swasta yaitu 126 orang (63\%), pengusaha sebanyak 18 orang $(9 \%)$, pelajar 30 orang $(15 \%)$, pegawai negeri sebanyak 7 orang (3.5\%) dan sisanya lain-lain sebanyak 19 0rang (9,5\%) lain-lain disini seperti ibu rumah tangga dan pensiunan. 
Tabel 2. Karakteristik Responden Menurut Pekerjaan

\begin{tabular}{|c|c|c|}
\hline Pekerjaan & $\begin{array}{c}\text { Jumlah Responden } \\
\text { (Orang) }\end{array}$ & $\begin{array}{c}\text { Persentase } \\
(\%)\end{array}$ \\
\hline Karyawan Swasta & 126 & $63 \%$ \\
\hline Pegawai Negeri & 7 & $3.50 \%$ \\
\hline Pelajar & 30 & $15 \%$ \\
\hline Pengusaha & 18 & $9 \%$ \\
\hline Lain-lain & 19 & $9.50 \%$ \\
\hline Total & 200 & $100 \%$ \\
\hline
\end{tabular}

Sumber: Data Penelitian, 2019

Responden terbanyak berjenis kelamin perempuan sebanyak 112 orang (56\%) dan responden laki-laki sebanyak 88 orang (44\%) dapat dilihat dalam Tabel 3.

Tabel 3. Karakteristik Responden Menurut Jenis Kelamin

\begin{tabular}{ccc}
\hline \multirow{2}{*}{ Jenis Kelamin } & Jumlah Responden & Persentase \\
\cline { 2 - 3 } & (Orang) & $(\%)$ \\
\hline Laki-laki & 88 & $44 \%$ \\
Perempuan & 112 & $56 \%$ \\
Total & 200 & $100 \%$ \\
\hline
\end{tabular}

Sumber: Data Penelitian, 2019

Berdasarkan jenis wisatawan, distribusi frekuensi responden dapat dilihat melalui Tabel 4. Wisatawan asing yang menjadi responden sebanyak 169 orang (84.5\%) berasal dari berbagai Negara seperti Australia, Canada, China, Inggris, Rusia, Saudi Arabia, Ukrania, Amerika dan lain sebagainya, sisanya adalah wisatawan domestik sebanyak 31 orang (15.5\%).

Tabel 4. Karakteristik Responden Menurut Jenis Wisatawan

\begin{tabular}{|c|c|c|}
\hline \multirow{2}{*}{ Jenis Wisatawan } & Jumlah Responden & Persentase \\
\hline & (Orang) & $(\%)$ \\
\hline Domestik & 31 & $15.50 \%$ \\
\hline Asing & 169 & $84.50 \%$ \\
\hline Total & 200 & $100 \%$ \\
\hline
\end{tabular}

Sumber: Data Penelitian, 2019

Uji Validitas diperoleh dengan cara mengkorelasi setiap skor indikator dengan total skor indikator variabel, kemudian hasil korelasi dibandingkan dengan nilai kritis pada taraf signifikan 0,05. Suatu kuesioner dikatakan valid jika pernyataan pada kuesioner mampu untuk mengungkapkan sesuatu yang akan diukur tersebut (Sugiyono, 2010). Hasil uji masing-masing validitas variabel terlihat dalam Tabel 5. sebagai berikut:

Berdasarkan $\mathrm{r}$ tabel, nilai Pearson Correlation minimal adalah 0.1381 karena menggunakan 200 responden $(\mathrm{N})$ dengan batas 0.05 . Terlihat variabel persepsi, marketing mix dan niat beli memiliki nilai pearson correlations tiap item diatas 0.1381. Jadi dapat disimpulkan bahwa seluruh indikator telah memenuhi syarat validitas data. 
Tabel 5. Hasil Uji Validitas

\begin{tabular}{|c|c|c|c|c|}
\hline \multirow{2}{*}{ No } & \multirow{2}{*}{ Variabel } & \multirow{2}{*}{ Indikator } & Koefisien & \multirow{2}{*}{ Keterangan } \\
\hline & & & Korelasi & \\
\hline \multirow{4}{*}{1} & \multirow{4}{*}{ Persepsi } & Persepsi 1 & 0.827 & Valid \\
\hline & & Persepsi 2 & 0.79 & Valid \\
\hline & & Persepsi 3 & 0.781 & Valid \\
\hline & & Persepsi 4 & 0.655 & Valid \\
\hline \multirow{11}{*}{2} & \multirow{11}{*}{ Marketing Mix } & Marketing Mix 1 & 0.845 & Valid \\
\hline & & Marketing Mix 2 & 0.85 & Valid \\
\hline & & Marketing Mix 3 & 0.801 & Valid \\
\hline & & Marketing Mix 4 & 0.856 & Valid \\
\hline & & Marketing Mix 5 & 0.677 & Valid \\
\hline & & Marketing Mix 6 & 0.708 & Valid \\
\hline & & Marketing Mix 7 & 0.732 & Valid \\
\hline & & Marketing Mix 8 & 0.807 & Valid \\
\hline & & Marketing Mix 9 & 0.416 & Valid \\
\hline & & Marketing Mix 10 & 0.646 & Valid \\
\hline & & Marketing Mix 11 & 0.545 & Valid \\
\hline \multirow{3}{*}{3} & \multirow{3}{*}{ Niat Beli } & Niat Beli 1 & 0.728 & Valid \\
\hline & & Niat Beli 2 & 0.578 & Valid \\
\hline & & Niat Beli 3 & 0.698 & Valid \\
\hline
\end{tabular}

Sumber: Data Penelitian, 2019

Hasil uji reliabilitas pada Tabel 6 menunjukkan seluruh instrumen penelitian dikatakan reliabel dimana keseluruhan .instrumen layak digunakan untuk mengumpulkan data. Nilai keseluruhan cronbach'salpha $\geq 0,6$ menunjukkan bahwa pengukuran tersebut dapat memberikan hasil yang konsisten apabila dilakukan pengukuran kembali terhadap subyek yang sama pada waktu yang berbeda

Tabel 6. Hasil Uji Reliabilitas

\begin{tabular}{lcc}
\hline \multicolumn{1}{c}{ Variabel } & Cronbach's Alpha & Keterangan \\
\hline Persepsi & 0.858 & Reliabel \\
Marketing Mix & 0.897 & Reliabel \\
Niat Beli & 0.897 & Reliabel \\
\hline
\end{tabular}

Sumber: Data Penelitian, 2019

Statistik deskriptif yang digunakan dalam penelitian ini yaitu nilai mean, standar deviasi, nilai maksimum dan minimum dari data, Hasilnya dapat dilihat dalam Tabel 7.

Tabel 7. Hasil Statistik Deskriptif

\begin{tabular}{lccccc}
\hline & N & Minimum & Maximum & Mean & Std. Deviation \\
\hline Persepsi & 200 & 4 & 20 & 7.04 & 3.37421 \\
Marketing Mix & 200 & 11 & 55 & 20.145 & 8.38064 \\
Niat Beli & 200 & 3 & 15 & 7.095 & 3.53816 \\
Valid N (listwise) & 200 & & & & \\
\hline Sumber: Data Penelitian, 2019 & & & &
\end{tabular}

Sumber: Data Penelitian, 2019 
Berdasarkan Tabel 7. dapat dijelaskan deskriptif statistik dari masingmasing variabel seperti nilai maksimum, minimum, nilai rata-rata dan standar deviasi. Penjelasan masing-masing variabel diuraikan sebagai berikut. A) Persepsi: Variabel persepsi memiliki nilai rata-rata sebesar 7,04 yang lebih besar dari nilai standar deviasi yaitu 3,37421. Besarnya nilai minimum 4,00 dan nilai maksimum 20,00. Nilai rata-rata yang lebih besar dari nilai standar deviasi menunjukkan bahwa secara umum responden setuju terhadap pernyataan yang diberikan pada indikator persepsi, sehingga dapat dikatakan bahwa gambaran yang ditampilkan oleh 'Dinner with The Great Elephant' dikategorikan baik. B) Marketing mix: Variabel marketing mix memiliki nilai rata-rata sebesar 20.1450 yang lebih kecil dari nilai standar deviasi yaitu 8.38064. Besarnya nilai minimum 11.00 dan nilai maksimum 55.00. Nilai rata-rata yang lebih rendah dari nilai standar deviasi menunjukkan bahwa terjadi fluktuasi pada pernyataan gambaran marketing mix 'Dinner with The Great Elephant' sehingga dikategorikan tidak baik. C) Niat Beli :Variabel niat beli memiliki nilai rata-rata sebesar 7.0950 yang lebih besar dari nilai standar deviasi yaitu 3.53816. Besarnya nilai minimum 3.00 dan nilai maksimum 15.00. Nilai rata-rata yang lebih besar dari nilai standar deviasi menunjukkan bahwa secara umum responden setuju terhadap pernyataan-pernyataan dari indikator Niat Beli, sehingga dapat dikatakan bahwa niat beli terhadap 'Dinner with The Great Elephant' dari aspek wisatawan dikategorikan baik.

Uji asumsi klasik pada penelitian ini dilakukan sebelum melakukan uji analisis jalur (path analysis). Pengujian ini bertujuan untuk menghindari adanya informasi bias dari sampel penelitian. Uji asumsi klasik di bawah ini terdiri dari uji normalitas, uji heteroskedastisitas, dan uji multikolinearitas masing-masing struktur atau model penelitian. Uji normalitas bertujuan untuk menguji apakah model regresi memiliki distribusi normal. Uji yang digunakan yakni uji statistik parametrik Kolomogorov-Smirnov. Normal atau tidaknya suatu data dilihat dari Sig (2-tailed), bila lebih besar dari taraf signifikansi 0,05 maka model regresi berdistribusi normal dan sebaliknya.

Tabel 8. Hasil Uji Normalitas

\begin{tabular}{lc}
\hline & Unstandardized residual \\
\hline $\mathrm{N}$ & 200 \\
Asymp. Sig. (2-tailed) & 0,62 \\
\hline
\end{tabular}

Sumber: Data Penelitian, 2019

Berdasarkan Tabel 8 menunjukkan bahwa besarnya nilai Asymp.Sig (2tailed) sebesar $0.062>0.05$, sehingga dapat disimpulkan bahwa data yang digunakan merupakan data yang berdistribusi normal. Uji heteroskedastisitas berfungsi untuk melihat ketidaksamaan varians dari residual pengamatan yang lain. Bila tingkat signifikansi dari masing-masing variabel lebih dari 0,05 maka bebas dari masalah heteroskedastisitas.

Tabel 9. Hasil Uji Multikolinearitas

\begin{tabular}{lc}
\hline Variabel & Signifikansi \\
\hline Persepsi & 0,220 \\
Marketing Mix & 0,324 \\
\hline
\end{tabular}

Sumber: Data Penelitian, 2019 
Hasil uji multikolinearitas pada Tabel 5.6 diatas menunjukkan bahwa nilai tolerance variabel bebas berada di atas 0.1 dan nilai VIF berada di bawah 10. Jadi dapat disimpulkan bahwa model tidak terdapat gejala multikolinearitas. Teknik analisis data yang digunakan dalam penelitian ini adalah analisis jalur (path analysis). Teknik analisis ini digunakan untuk mencari pengaruh langsung dan tidak langsung variabel independen pada variabel dependen melalui variabel intervening.

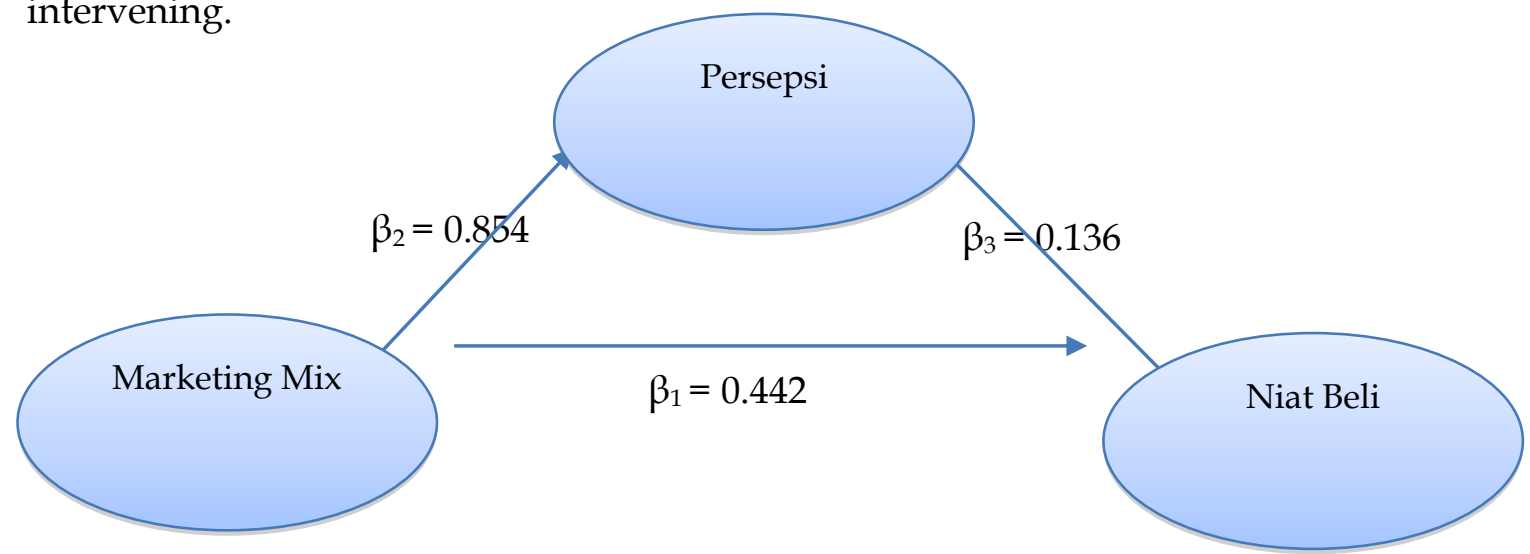

Gambar 2. Model Diagram Jalur Peran Persepsi dalam memediasi Marketing Mix Terhadap Niat Beli

Sumber: Data Penelitian, 2019

Persamaan yang diperoleh dari hasil analisis jalur adalah :

- Persepsi $=0.854$ Marketing Mix $+\mathrm{e}_{1}$

- Niat Beli $=0.442$ Marketing Mix +0.136 Persepsi $+\mathrm{e}_{1}$

Berdasarkan hasil dari koefisien jalur pada hipotesis penelitian, maka dapat digambarkan hubungan kausal antar variabel marketing mix, persepsi terhadap niat beli. Perhitungan pengaruh antar variabel dirangkum dalam Tabel 10 berikut.

Tabel 10. Pengaruh Langsung dan Pengaruh Tidak Langsung serta Pengaruh Total Marketing Mix, Persepsi dan Niat Beli

\begin{tabular}{llclc}
\hline \multicolumn{1}{c}{$\begin{array}{c}\text { Pengaruh } \\
\text { Variabel }\end{array}$} & $\begin{array}{c}\text { Pengaruh } \\
\text { Langsung }\end{array}$ & $\begin{array}{l}\text { Pengaruh Tidak } \\
\text { Langsung }\left(\beta_{2 \times} \beta_{3}\right)\end{array}$ & $\begin{array}{c}\text { Pengaruh } \\
\text { Total }\end{array}$ \\
\hline$\beta_{1}$ & Marketing Mix $\rightarrow$ Niat Beli & 0.442 & $\left(0.854^{*} 0.136\right)=$ & 0.558 \\
& & & 0.116 & \\
$\beta_{2}$ & Marketing Mix $\rightarrow$ Persepsi & 0.854 & - & 0.854 \\
$\beta_{3}$ & Persepsi $\rightarrow$ Niat Beli & 0.136 & - & 0.136 \\
\hline
\end{tabular}

Sumber: Data Penelitian, 2019

Dalam Uji Heterokedastisitas terlihat bahwa nilai signifikan 0.000 lebih kecil dari 0.05 ini berarti bahwa pada Regresi Model I variabel marketing mix berpengaruh signifikan terhadap persepsi. R Square sebesar 0.729 menunjukan bahwa kontribusi variabel marketing mix terhadap persepsi adalah sebesar $72.9 \%$ sementara sisanya $27.1 \%$ dipengaruhi variabel lain diluar penelitian. Untuk nilai e1 dapat dicari dengan rumus e $1=\sqrt{0.271}=0.520$. Dengan demikian diperoleh diagram jalur model struktur I sebagai berikut : 


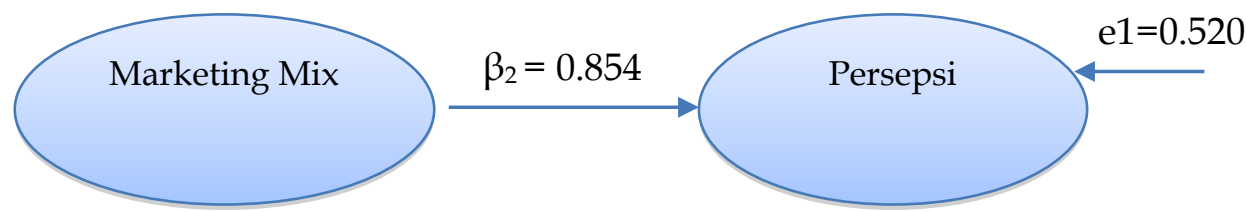

Gambar 3. Diagram Jalur Model Struktur I

Sumber: Data Penelitian, 2019

Dalam Uji Heterokedastisitas terlihat bahwanilai signifikan variabel marketing $\operatorname{mix}=0.000$ dan persepsi $=0.030$ lebih kecil dari 0.05 . Hal ini berarti bahwa Regresi Model II, yakni variabel marketing mix dan persepsi berpengaruh signifikan terhadap niat beli. $R$ Square yang terdapat pada sebesar 0.316 artinya kontribusi variabel marketing mix dan persepsi terhadap niat beli adalah sebesar $31.6 \%$ sementara sisanya $68.4 \%$ dipengaruhi variabel lain diluar penelitian. Untuk nilai e2 dapat dicari dengan rumus e2 $=\sqrt{0.684}=0.827$. Dengan demikian diperoleh diagram jalur model struktur II sebagai berikut :

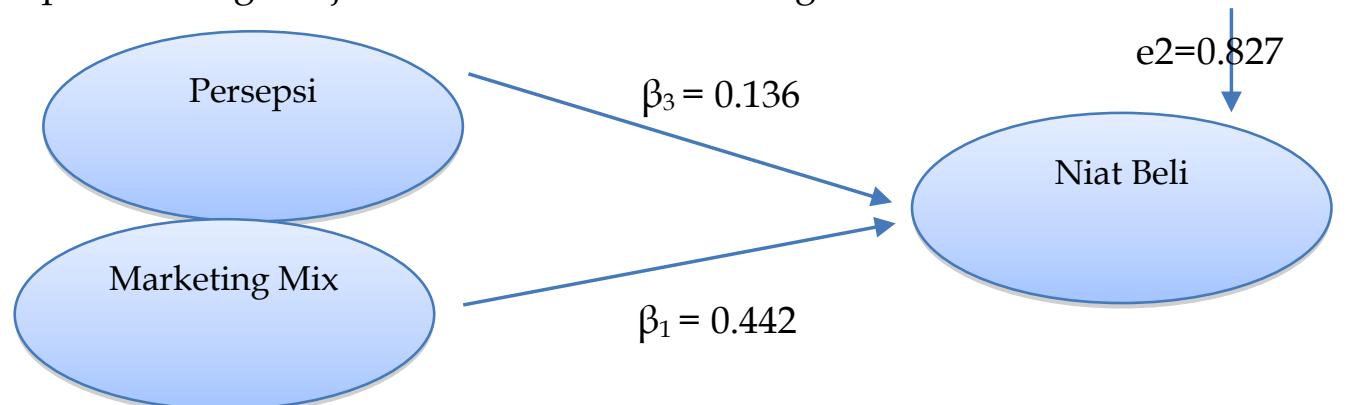

Gambar 4. Diagram Jalur Model Struktur II

Sumber: Data Penelitian, 2019

Uji Sobel merupakan alat analisis untuk menguji signifikansi dari hubungan tidak langsung antara variabel independen dengan variabel dependen yang dimediasi oleh variabel mediator. Nilai $t$ hitung dibandingkan dengan nilai $t$ tabel yaitu $\geq 1,96$. Jika nilai $t$ hitung lebih besar dari $t$ tabel, maka dapat disimpulkan terjadi pengaruh mediasi.

$$
\begin{aligned}
& S a b=\sqrt{b^{2} S_{a}^{2}+a^{2} S_{b}^{2}+S_{b}^{2}+S_{a}^{2} S_{b}^{2}} \\
& S a b=\sqrt{\left(0.136^{2}\right)\left(0.119^{2}\right)+\left(0.854^{2}\right)\left(0.015^{2}\right)+\left(0.119^{2}\right)\left(0.119^{2}\right)} \\
& S a b=\sqrt{0.0004} \\
& S a b=0.0200 \\
& \mathrm{t} \quad=\frac{a b}{S a b} \\
& \mathrm{t} \quad=\frac{(0.136)(0.854)}{0.0200} \\
& \mathrm{t} \quad=5.80 \\
& \mathrm{t} \text { hitung }(5.80)>\mathrm{t} \text { tabel }(1.96)
\end{aligned}
$$

Berdasarkan perhitungan uji Sobel, didapatkan nilai $t$ hitung sebesar 5.80 lebih besar dari $t$ table 1.96. Dapat disimpulkan bahwa persepsi mampu memediasi pengaruh marketing mix terhadap niat beli wisatawan. Uji Koefisien Determinasi ( $\mathrm{R}$ Square) bertujuan untuk mengetahui besarnya pengaruh variabel-variabel bebas terhadap variabel terikat. Hasil analisis menunjukkan hasil Adjusted $\mathrm{R}^{2}$ sebesar 0.316 sehingga dapat dihitung dengan rumus sebagai berikut:

Determinasi $\quad=0.316 \times 100 \%$ 
Tabel 11. Uji Determinasi

$$
=31.6 \%
$$

\begin{tabular}{crrrr}
\hline Model & $\mathrm{R}$ & R Square & $\begin{array}{c}\text { Adjusted } R \\
\text { Square }\end{array}$ & $\begin{array}{c}\text { Std. Error of the } \\
\text { Estimate }\end{array}$ \\
\hline 1 & $.562(\mathrm{a})$ & 0.316 & 0.309 & 1.84044 \\
\hline
\end{tabular}

Sumber: Data Penelitian, 2019

Berdasarkan Tabel 11. besarnya nilai koefisien determinasi sebesar $31.6 \%$ menunjukkan bahwa kontribusi variabel marketing mix dan persepsi terhadap niat beli sebesar $31.6 \%$ sedangkan sisanya sebesar $68.4 \%$ dipengaruhi oleh variabel lain di luar model penelitian. Uji statistik $F$ pada dasarnya menunjukkan bahwa variabel independen yang dimasukan dalam model mempunyai pengaruh secara bersama-sama terhadap variabel dependen. Nilai signifikansi annova $\leq a=0.05$ maka model ini dikatakan layak atau variabel independen mampu menjelaskan variabel dependen.

Tabel 12. Uji F

\begin{tabular}{|c|c|c|c|c|c|c|}
\hline Model & & $\begin{array}{l}\text { Sum of } \\
\text { Squares }\end{array}$ & $\mathrm{df}$ & Mean Square & $\mathrm{F}$ & Sig. \\
\hline \multirow[t]{3}{*}{1} & Regression & 787.897 & 2 & 393.948 & 45.563 & $.000(a)$ \\
\hline & Residual & 1703.298 & 197 & 8.646 & & \\
\hline & Total & 2491.195 & 199 & & & \\
\hline
\end{tabular}

Sumber: Data Penelitian, 2019

Oleh karena nilai sig $0.000<0.05$ maka dapat disimpulkan bahwa terdapat pengaruh yang signifikan variabel marketing mix dan persepsi terhadap niat beli. Pengujian hipotesis I bertujuan untuk menganalisis pengaruh marketing mix terhadap niat beli wisatawan. Variabel marketing mix memiliki nilai koefisien beta positif sebesar 0.442 dengan tingkat signifikansi sebesar $0.000<0.05$. Hasil ini mengindikasikan bahwa marketing mix berpengaruh positif signifikan terhadap niat beli wisatawan, sehingga membuktikan bahwa semakin baik marketing mix yang ditawarkan maka semakin tinggi niat belinya. Menurut (Kotler \& Keller, 2008) perusahaan sebaiknya perlu secara matang mempertimbangkan pemilihan lokasi usaha untuk pengembangan masa depan. Peranan penetapan harga akan menjadi sangat penting terutama dalam keadaan persaingan yang semakin tajam dan perkembangan permintaan yang terbatas. (Swastha, 2014) menyatakan bahwa promosi dipandang sebagai kegiatan komunikasi pembeli dan penjual dan merupakan kegiatan yang membantu dalam pengambilan keputusan di bidang pemasaran serta mengarahkan dan menyadarkan semua pihak untuk berbuat lebih baik. Hasil penelitian ini sejalan dengan penelitian yang dilakukan oleh (Fure, 2013) menyatakan bahwa produk dan lokasi berpengaruh signifikan terhadap niat beli.

Pengujian hipotesis II bertujuan untuk menganalisis pengaruh marketing mix terhadap persepsi wisatawan. Variabel marketing mix memiliki nilai koefisien beta positif sebesar 0.854 dengan tingkat signifikansi sebesar $0.000<$ 0.05. Hasil ini mengindikasikan bahwa marketing mix berpengaruh positif dan signifikan terhadap persepsi wisatawan. Sehingga penelitian ini membuktikan bahwa semakin baik marketing mix yang ditawarkan maka semakin tinggi persepsinya. Rustandi (2012) menyatakan bahwa produk mempengaruhi 
persepsi, selain itu (Tjiptono, 2008) menyatakan bahwa dasar pengambilan keputusan pembelian dapat dilihat melalui atribut produk. Hasil penelitian ini sejalan dengan penelitian yang dilakukan oleh (Wardhani, Sumarwan, \& Yuliati, 2016) faktor produk berpengaruh secara signifikan terhadap persepsi konsumen. Penelitian (Fure, 2013) Lokasi berpengaruh signifikan terhadap minat beli konsumen.

Pengujian hipotesis III bertujuan untuk menganalisis pengaruh persepsi terhadap niat beli wisatawan. Variabel persepsi memiliki nilai koefisien beta positif sebesar 0.136 dengan tingkat signifikansi sebesar $0.030<0.05$. Hasil ini mengindikasikan bahwa persepsi berpengaruh positif dan signifikan terhadap niat beli wisatawan. Sehingga penelitian ini membuktikan bahwa semakin baik persepsi yang ditawarkan maka semakin tinggi niat belinya. Konsumen akan menampakan perilaku setelah melakukan persepsi terhadap keputusan apa yang diambil dalam membeli suatu produk (Wahyuni,2008). Merk bukan hanya symbol, namun merek juga memberikan arti bahwa suatu produk mempunyai nilai tertentu (Pepadri, 2002). Hasil penelitian ini sejalan dengan penelitian yang dilakukan oleh (Suarjana, K,. Suprapti, 2018) menyatakan bahwa persepsi harga berpengaruh positif dan signifikan terhadap niat beli. Penelitian (Novansyah, 2016) juga menyebutkan persepsi merek mewah berpengaruh positif dan signifikan terhadap niat beli.

Pengujian hipotesis IV bertujuan untuk menganalisis peran persepsi dalam memediasi marketing mix terhadap niat beli. Hasil pengujian pengaruh tidak langsung marketing mix terhadap niat beli melalui persepsi menujukkan bahwa nilai t hitung sebesar 5.80 yang lebih besar dari 1.96. Hasil ini menunjukkan bahwa persepsi mampu memediasi pengaruh marketing mix terhadap niat beli wisatawan. Sehingga penelitian ini membuktikan bahwa semakin baik marketing mix yang ditawarkan maka semakin tinggi niat beli melalui persepsi. Persepsi memediasi marketing mix terhadap niat beli secara parsial yaitu marketing mix berpengaruh signifikan terhadap niat beli dan persepsi, serta persepsi berpengaruh signifikan terhadap niat beli. Persepsi didefinisikan oleh (Kotler \& Keller, 2008) sebagai proses seorang individu dalam memilih, mengorganisasikan dan menafsirkan masukan dan informasi untuk menciptakan sebuah gambar yang bermakna tentang dunia. Persepsi merupakan aktivitas penting yang menghubungkan konsumen individual dengan kelompok, situasi dan pengaruh pemasaran (Hawkins DI, Motherbaugh, David, 2013). Hasil penelitian ini sejalan dengan penelitian yang dilakukan oleh Rizka (2016) menyatakan persepsi nilai, persepsi merek dan persepsi harga secara simultan berpengaruh signifikan terhadap minat berkunjung wisatawan.

\section{SIMPULAN}

Berdasarkan hasil perhitungan variabel marketing mix memiliki nilai koefisien beta positif sebesar 0.442 dengan tingkat signifikansi sebesar $0.000<0.05$. Hasil ini menunjukkan bahwa marketing mix berpengaruh positif dan signifikan terhadap niat beli wisatawan. Berdasarkan hasil perhitungan variabel marketing mix memiliki nilai koefisien beta positif sebesar 0.854 dengan tingkat signifikansi sebesar $0.000<0.05$. Hasil ini menunjukkan bahwa marketing mix berpengaruh positif signifikan terhadap persepsi wisatawan. Berdasarkan hasil perhitungan 
variabel persepsi memiliki nilai koefisien beta positif sebesar 0.136 dengan tingkat signifikansi sebesar $0.030<0.05$. Hasil ini menunjukkan bahwa persepsi berpengaruh positif dan signifikan terhadap niat beli wisatawan. Berdasarkan hasil pengujian pengaruh tidak langsung marketing mix terhadap niat beli melalui persepsi menujukkan bahwa nilai thitung sebesar 5.80 yang lebih besar dari 1.96. Hasil ini menunjukkan bahwa persepsi mampu memediasi pengaruh marketing mix terhadap niat beli wisatawan. Hasil menunjukkan bahwa persepsi memediasi marketing mix terhadap niat beli secara parsial. Saran yang dapat diberikan berdasarkan simpulan yang dipaparkan kepada perusahaan, khususnya program 'Dinner with the Great Elephant' di Bali Zoo serta peneliti yang selanjutnya mengangkat topik serupa adalah 1) Hasil pengolahan data dalam deskripsi variabel marketing mix yaitu produk (product), promosi (promotion), harga (price) dan lokasi (place), menunjukkan rata-rata tidak baik dimana nilai rata-rata 20,14 jauh lebih kecil dari standar deviasi 8,38 yang artinya banyak responden tidak setuju dengan pernyataan dalam kuesioner, oleh karena itu manajemen Bali Zoo perlu memperhatikan marketing mix yang ditawarkan terutama pada produk seperti produk yang membangkitkan rasa ingin tahu wisatawan, produk yang unik, penawaran pengalaman yang bernilai dan tampilan promosi yang lebih menarik dan lebih mudah dikenali oleh wisatawan 2) Peneliti selanjutnya diharapkan memperluas ruang lingkup penelitian, menambah variabel penelitian, serta melakukan penelitian secara periodik (time series) agar diperoleh hasil penelitian yang riil dan aktual.

\section{REFERENSI}

Aggrawal, A. (2010). Impact of Consumer Perception on Buying Behavior in Apparel Retail Sector, with special reference to selected Indian Cites. Patil University, Departement of Business Management.

Alayka, H., \& Astuti, S. (2015). Analisis Pengaruh Kualitas Produk, Persepsi Harga Dan Promosi Terhadap Keputusan Pembelian Honda Revo FIT FI. journal of management.

Alma, B. (2011). Pemasaran dan Pemasaran Jasa. In B. Alma, Pemasaran dan Pemasaran Jasa.

Arkdeniz, A. (2015). Effect of Perceived Values on the Brand Preference and The Purchase Intention. european scientific, 8(17), 1-17.

Arnould, E.J.,Price,L. and Zinkhan, G. (2002). Consumers. Boston: McGraw-Hill.

Arokiosamy. A.Raj. (2012). The Effect of Marketing Mix and Customer Perception on Brand Loyalty. Journal of Business and Management, 4(2), 0111.

Arsinta, G.A.P,.Purnami, N. (2015). Peran Persepsi Nilai dalam Memediasi Pengaruh Kredibilitas Celebrity Endorser pada Niat Beli Produk Kosmetik Maybelline di Kota Denpasar. JMatrik: Jurnal manajemen, Strategi Bisnis dan Kewirausahaan, 9(2), pp: 123-134.

Bachriansyah, R. (2011). Analisis Pengaruh Kualitas Produk, Daya Tarik Iklan, dan Persepsi harga Terhadap Minat Beli Konsumen Pada Produk Ponsel Nokia (Studi Kasus Pada Masyarakat Di Kota Semarang). Fakultas Ekonomi dan Bisnis Universitas Diponegoro. 
Bono, H. (2006). Perceived Value: When Considering Value, perception can be as Important as Reality. Retrieved from www.thinkingmanagres.com/management/perceivedvalue

Bosnjak, M., Obermeier, D., \& Tuten, T. (2006). Predicting and explaining the propensity to bid in online auctions: a comparison of two actiontheoretical models. Journal of Consumer Behaviour.

Dhiba, I., \& Maduwinarti, A. (2014). Analisis Pengaruh Bauran Pemasaran Jasa Terhadap Minat Pengunjung Pada Obyek Wisata Museum Kesehatan Dr. Adhyatma, MPH Surabaya. Jurnal Ilmu Ekonomi \& Manajemen.

Dodds, W., Monroe, K., \& Grewal, D. (1991). Effects of Price, Brand, and Store Information on Buyers' Product Evaluations. Journal of Marketing Research.

Fure, H. (2013). Lokasi, Keberagaman Produk, Harga dan Kualitas Pelayanan Pengaruhnya Terhadap Minat Beli Pada Pasar Tradisional Bersehati Calaza. Jurnal EMBA, 1, 273-283.

Gitosudarmo, I. (2008). Manajemen Pemasaran (kedua cetakan ke-6 ed.). Yogyakarta: Penerbit: BPFE .

Han, H., \& Ryu, K. (2009). The roles of the physical environment, price perception, and customer satisfaction in determining customer loyalty in the restaurant industry. Journal of Hospitality and Tourism Research.

Hansudoh, S. (2012). Pengaruh Celebrity Endorsment Terhadap Purchase Intention Melalui Perceived Value Pada Produk Top Coffee di Surabaya. E-Journal Universitas Katolik Widya Mandala , 1(5) , pp:1-7.

Hawkins DI, Motherbaugh, David, L. (2013). Consumer Behavior: Building Marketing Strategy. New York (US): New York (US) : Mc- Graw Hill Companies, Inc.

Kotler, P. \& Armstrong, G. (2008). Prinsip-Prinsip Pemasaran. Edisi 12. Jilid 1.

Kotler, P., \& Keller, K. (2008). Manajemen pemasaran, 13th Edition, Vol. 2.

Kusdyah, I. (2012). Persepsi Harga, Persepsi Merek Persepsi Nilai, Dan Keinginan Pemebelian Ulang Jasa Clinic Kesehatan (Studi Kasus erha Clinic Surabaya). Jurnal Manajemen Pemasaran, Vol (1). , Pp 25-32.

Kusumaningrum, D. (2009). Persepsi Wisatawan Nusantara Terhadap Daya Tarik WisataDi Kota Palembang. Universitas Gadjah Mada. Magister Kajian Pariwisata.

Lear, K., Runyan, R., \& Whitaker, W. (2009). Sports celebrity endorsements in retail products advertising. International Journal of Retail $\mathcal{E}$ Distribution Management.

Listyorini, S. (2012). Analisis Faktor-Faktor Gaya Hidup dan Pengaruhnya Terhadap Pembelian Rumah Sehat Sederhana Studi Pelanggan Rumah Dinar Mas PT Ajisaka Semarang. Jurnal Administrasi Bisnis Undip, 1(1). , Pp 12-24.

Lupiyoadi. (2011). Manajemen Pemasaran Jasa Teori dan Praktik.

Murphy, P., Pritchard, M., \& Smith, B. (2000). The destination product and its impact on traveller perceptions. Tourism Management.

Novansyah, T. (2016). Pengaruh Persepsi Merek Mewah, Citra Merek dan Kualitas Produk terhadap Niat Beli Konsumen Zara di Surabaya. Retrieved from Perbanas.ac.id 
Pendit, I. (1999). Ilmu Pariwisata, Sebuah Pengantar Perdana (cetakan ke-6 ed.). Jakarta: PT Pradnya Paramita.

Pepadri, I. (2002). Pricing is The Moment of Truth, All Marketing Comes to Focus in the Pricing Decision. Retrieved from http:/ / xa.yimg.com/kq/groups/15493189/321631/88/name/pricing+th e+moment+of+thruth.pdf

Rahman, O. (2011). Understanding consumer's perception and behaviours: implications for denim jeans design. Journal of Textile an Apparel Technology and Management, 7(1), Pp. 1-16.

Robbins, S. (1996). Organizational Behavior: Concepts, Controversies and Applications.

Schiffman and Lazar Kanuk. (2000). Costumer Behaviour. International Edition, Prentice Hall.

Stamboulis, Y., \& Skayannis, P. (2003). Innovation strategies and technology for experience-based tourism. Tourism Management.

Stephanie, E. (2013). Pengaruh Kredibilitas Endorser Terhadap Minat Beli Melalui Sikap Atas Iklan Produk Shampoo Loreal di Surabaya. Jurnal Universitas Surabaya(2(2), pp: 1-21), pp: 1-21.

Suarjana, K,. Suprapti, N. (2018). Pengaruh Persepsi Harga, Pengetahuan Produk, Dan Citra Perusahaan terhadap Niat Beli Layanan Multi Servis Merek Indihome. E-Jurnal Manajemen Unud, Vol 7(4), Pp 1920-1949.

Sugiyono. (2010). Metode Penelitian Bisnis. Pendekatan Kuantitatif, kualitatif dan R \& D. Bandung: Alfabeta.

Suprapti, N. (2010). Perilaku konsumen: Pemahaman dasar dan aplikasinya dalam strategi pemasaran. Bali: Universitas Udayana Bali.

Sutopo, I., S. (2016). Analisis Pengaruh Produk Wisata, Persepsi Harga dan Promosi Terhadap Keputusan Wisatawan Dalam Mengunjungi Obyek Wisata (Studi pada Objek Wisata Puri Merokoco Kota Semarang). Diponegoro Journal of Management, Vol 5(No 4), Pp 1-10.

Swastha, B, I. (2014). Manajemen Pemasaran Modern.

Swastha, B. (2014). Manajemen Pemasaran. Yogyakarta: BPFE.

Tjiptono, F. (2008). Strategi Pemasaran.Edisi ke-1. Yogyakarta (ID): Andi Offset (Edisi ke-1 ed.). Yogyakarta: Andi Offset.

Tsiotsou, R., \& Ratten, V. (2010). Future research directions in tourism marketing. Marketing Intelligence and Planning.

Vaniia. (2012). Persepsi Konsumen. Retrieved from http://vaniariyanti.blogspot.co.id/2012/05/persepsi-konsumenpengertian-persepsi.html

Wardhani, W., Sumarwan, U., \& Yuliati, L. (2016). Pengaruh Persepsi dan Preferensi Konsumen terhadap Keputusan Pembelian Hunian Green Product. Jurnal Manajemen dan Organisasi, 6(1), 45.

Wiryantari, I,C., d. (2016). Peran persepsi Nilai Dalam Memediasi Pengaruh Kredibilitas Celebrity Endorser Pada Niat Beli Produk Kosmetik Wardah. E-Jurnal Manajemen Unud, Vol 5,(No.11), pp 7100-7172.

Zeithaml VA. (2000). Consumer perception of price, quality and value: a meansend model and synthesis for evidence. Journal of Marketing, 52(3), 2-22. 